\title{
The Resurrection of the Body AND THE RUIN OF THE WORLD
}

Kissed for the first time, I was cornered behind a tree at recess by Heather Wilson. Until I stung she pressed me into the bark, until my shirt was sap-specked, hung. I wrenched from her, the clumsy pop between us, my nervous word, echoing as I ran, dizzy scared, cotton mouthed. On show-and-tell day our courtship ended: Heather was to perform for class a baton twirling routine. Desks were moved, a turn table set up, she changed into spangles for that lumen hour. Her emergent shimmer she dedicated to Kent Goodwin, skewering me clean through as the record needle dropped onto the hazy groove of Eddie Rabbit's "I Love A Rainy Night," a 45 I sometimes find in jukeboxes or on dying AM radio stations no one knows how to hear anymore. Tonight's damp quiet falls from the roof like bits of soap or snowat night Chicago radio is clear. Sometimes Toronto if it is cold, the sky scrubbed raw. I say names out loud because the air's a poor listener, the best forgiver. Questionable behavior, I know, that leads me to the questionable science of those who believe the voice's energy is undiminished by time, its thin diatoms furl forever through air, as if the sky were a giant chalk conch spiraled from the dirt up and away from us, returning 
not a siren's empty set, white noise, not the ocean's licking whisper, but the muddle of all lapsed talk, that, for example, we might reclaim Lincoln reading the Emancipation Proclamation from the ionosphere. That we might flicker once more the first words of love that from our mouths were lit candles falling through napalm.

That the shortest distance is not one, but zero.

Here come the lost spears I threw from a flashlight into the night skyand there they go. So simple and straight there could never be anything curved or crooked, not smiles, not teeth, lips, voices or lives. And yet I snapped my spine in two places like a charred wick when I was twelve. Kent Goodwin died a year before from an undiagnosed brain tumor. The dead in Christ shall rise again, shall bring to my father's mouth the hush that comes at odd times when he quotes the book of Job to me: When he hath tried me, I shall come forth as gold. It's then that tears might be unworkablethe body only a house-fire, a hard, bloody cough into the fist that leaves each eye a pincushion of embers. There they go. Dusk fireflies, sparklers, a silver baton, world without end. Inside, the radio is haze through the dark as I hold my breath, as my lover asks before taking me into her mouth.

All the gods of love die once more.

I watch her hair fall forward

along the lines of her face, draping

over my hips. It blurs into

the question she'll ask later, if it's mussed. 
No, I'll say, but now I imagine nerve endings

that wire through each strand

on her head as I touch the heel of my palm

to her and shudder. She seems to drift through me slowly, and yet stays.

Into the dark I go more than I come

and on my way I give my mind

to voices that speak beyond ideas of gravity,

that do not rise or fall, or bloom

as we imagine the humid lives of lilacs.

I'm hardly there; but here-

small and distant

as a star whose light quickened long before

tonight. The voice

of a lost friend places its mouth on mine

and all I can think of is stopping

his words that lurch even after weeks,

that Heather's now a lesbian grocery cashier

in a town miles removed.

Despite insistence I don't care, he winks, saying,

c'mon, you know you drove her to it, you'd pay to watch. 